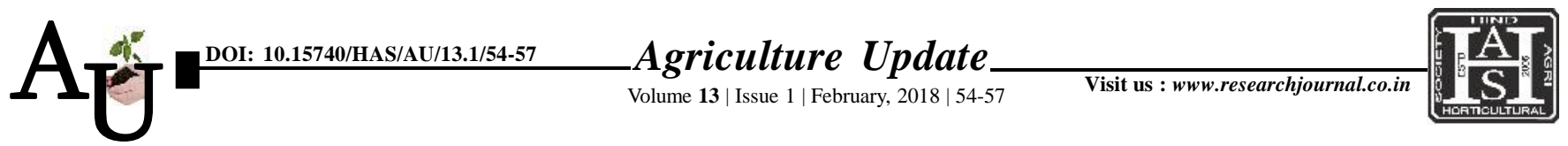

a e ISSN-0976-6847

\title{
Research article: Callus induction from different explants in cowpea (Vigna unguculata L.)
}

A. Srujana and J. Naga Lakshmi

Article Chronicle: Received :

06.11.2017;

Revised :

19.12.2017;

Accepted :

05.01.2018

KEY WoRDS :

Herbaceous, Callus, Regeneration, Harvested, Fodder combination of 2, 4-D+KN.
SUMMARY : Cowpea (Vigna unguiculata L.) is widely cultivated throughout the world. Cowpea is an important tropical herbaceous legume crop and is cultivated in dry (low rainfall) and nutritionally poor soils. Cowpea plays a major role in human nutrition not only because of its good protein quality with a high nutritional value but also because cowpea is critical for feeding animals during the dry season in many parts of West Africa. Moreover, cowpea is a valuable source of income for farmers and grain traders of this region. The genus Vigna currently includes around 80 species distributed throughout the tropics. It can be cultivated in diverse climatic and soil conditions. There are many reports in the cowpea tissue culture, the existing problems and the prospective in regeneration are highlighted although this plant appears to be the most recalcitrant to in-vitro regeneration. In the present study the explants respond to the culture medium to produced profuse callus. The maximum callus produced was in the

How to cite this article : Srujana, A. and Lakshmi, J. Naga (2018). Callus induction from different explants in cowpea (Vigna unguculata L.). Agric. Update, 13(1): 54-57; DOI : 10.15740/HAS/AU/13.1/54-57.

\section{Author for correspondence :}

\section{A. Srujana,} Department of Botany, Osmania University, Hyderabad (Telangana) India

See end of the article for authors' affiliations 